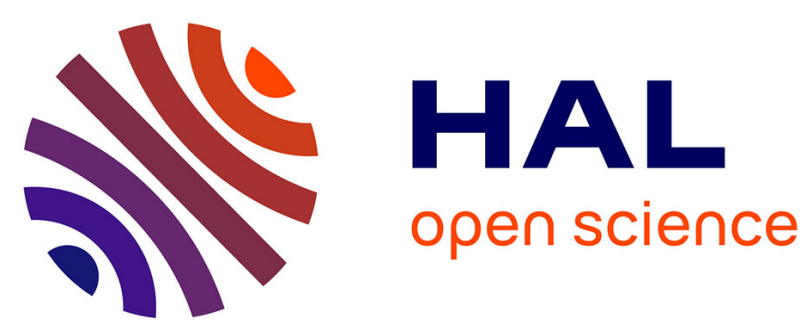

\title{
Erratum: Kinetic Study of the Linear Ising Chain. Comparison with Ultrasonic Absorption Measurements in Solutions of Polypeptides
}

\author{
Y. Dormoy, R. Cerf
}

\section{- To cite this version:}

Y. Dormoy, R. Cerf. Erratum : Kinetic Study of the Linear Ising Chain. Comparison with Ultrasonic Absorption Measurements in Solutions of Polypeptides. Journal de Physique Lettres, 1976, 37 (11), pp.321-321. 10.1051/jphyslet:019760037011032100 . jpa-00231302

HAL Id: jpa-00231302

https://hal.science/jpa-00231302

Submitted on 1 Jan 1976

HAL is a multi-disciplinary open access archive for the deposit and dissemination of scientific research documents, whether they are published or not. The documents may come from teaching and research institutions in France or abroad, or from public or private research centers.
L'archive ouverte pluridisciplinaire HAL, est destinée au dépôt et à la diffusion de documents scientifiques de niveau recherche, publiés ou non, émanant des établissements d'enseignement et de recherche français ou étrangers, des laboratoires publics ou privés. 


\title{
ERRATUM
}

J. Physique Lett. 37 (1976) L-265

Kinetic Study of the Linear Ising Chain.

Comparison with Ultrasonic Absorption Measurements in Solutions of Polypeptides

\author{
Y. DORMOY and R. CERF
}

- Pages L-268 bas et L-269 haut, lire :

1) When the chain length is not less than the cooperativity length multiplied by a factor of several units, the four rate equations that govern the relevant probabilities for a long chain can be applied.

2) The smaller the chain-length, however, the larger we must choose the value of $\overline{\Delta V} / \delta V$, in accordance with the mechanism that we assume is producing $\overline{\Delta V}$. 